\title{
Photoprotective substances in Antarctic macroalgae and their variation with respect to depth distribution, different tissues and developmental stages
}

\author{
Kirsten Hoyer*, Ulf Karsten**, Thomas Sawall, Christian Wiencke \\ Alfred Wegener Institute for Polar and Marine Research, Am Handelshafen 12, 27570 Bremerhaven, Germany
}

\begin{abstract}
In this study the distribution pattern of UV-absorbing mycosporine-like amino acids (MAAs) was identified and quantified in Antarctic macroalgae and correlated with habitat as well as with the radiation climate in air and under water. In addition, specific amounts of MAAs from selected species collected at different depths, from different parts of the thallus and developmental stages were investigated. Seven different MAAs were detected in 17 out of 28 red algal species, whereas in all brown and 2 green algal species only traces of MAAs were found. In the green alga Prasiola crispa ssp. antarctica a high concentration of an unknown UV-absorbing substance with an absorption maximum at $324 \mathrm{~nm}$ was detected. MAA content was negatively correlated with water depth. Higher concentrations of UV-absorbing substances were found in the marginal tissues of thalli than in the basal parts. Tetrasporophytes and gametophytes exhibited similar MAA values. After transplantation from deep to shallow water, the MAA content remained unchanged for $8 \mathrm{~d}$ after transplantation. The data presented indicate 3 physiologically different groups of algae in terms of MAA values: (1) species with no capability for MAA biosynthesis; (2) species with a basic MAA concentration which is adjusted relative to changes in environmental radiation; (3) species with a constant relatively high MAA composition and concentration irrespective of environmental conditions.
\end{abstract}

KEY WORDS: Antarctica $\cdot$ Macroalgae $\cdot$ Mycosporine-like amino acids $\cdot$ UV-absorbing compounds · UV radiation

\section{INTRODUCTION}

Due to the depletion of the stratospheric ozone layer, solar ultraviolet-B radiation (UVBR) is increasing on the earth's surface particularly over the Antarctic region. The decrease in the ozone concentration during the Antarctic spring (September to November) is normally most pronounced in October (Lubin \& Frederick 1989). The lowest ozone concentration ever recorded was measured in September 1998. This value is only about $25 \%$ of the mean concentration measured in the late 1960s (World Meteorological Organization 1998). Consequently, surface erythemal UV doses in spring had

\footnotetext{
*E-mail: khoyer@awi-bremerhaven.de

${ }^{* *}$ Present address: University of Rostock, Institute of Aquatic Ecology, 18051 Rostock, Germany
}

increased by about $130 \%$ compared to the 1960 s (Madronich et al. 1998).

UVBR is known to harm many biological processes, and may induce direct mutagenic and lethal effects by damage to DNA, changes in enzymatic activity, and reduction of photosynthetic efficiency (Strid et al. 1994). Besides terrestrial biota, aquatic organisms are also strongly affected because UVBR can penetrate the water column to depths of 10 to 30 m (Karentz 1989, Bischof et al. 1998a), in Antarctic waters even down to 60-70 m (Smith et al. 1992).

Benthic macroalgae play an important role in Antarctic (coastal) shallow-water ecosystems (Klöser et al. 1994, Gómez et al. 1997). These plants serve as a habitat for mobile and sessile invertebrates such as gastropods and bryozoans, as a food source for herbivores and detrivores, as well as nursery areas for juve- 
nile animals such as fishes and crustaceans (Iken et al. 1999).

UVBR has many negative effects on macroalgae, such as reduction of growth, reproduction and productivity (Dring et al. 1996, Aguilera et al. 1999), inhibition of photosynthetic activity especially in deep-water species (Larkum \& Wood 1993, Hanelt et al. 1997, Bischof et al. 1998b, Gómez et al. 1998), and on the quantity and quality of photosynthetic pigments (Wood 1987). The main molecular targets are DNA, RNA and proteins, which strongly absorb UVBR. However, macroalgae have developed protective mechanisms which counteract the effects of UVBR stress. At the molecular level there is the capability to repair DNA damage by photolyases and excision enzymes. In addition, there are also physiological and biochemical counteracting strategies such as the expression of detoxifying enzymes for the elimination of UVR-induced reactive oxygen species (Collén \& Davison 1999).

Moreover, many marine primary producers synthesize UV-absorbing substances, known as mycosporine-like amino acids (MAAs) (Riegger \& Robinson 1997, Dunlap \& Shick 1998, Karsten et al. 1998a, Franklin et al. 1999, Jeffrey et al. 1999, Karsten \& Wiencke 1999). These compounds are considered as a passive sunscreen mechanism which protects against damaging UV radiation through absorption of these photons followed by heat and fluorescence emission (Cockell \& Knowland 1999). To date, 19 structurally distinct MAAs have been identified in marine organisms. MAAs are water-soluble compounds characterized by a cyclohexenone or cyclohexenimine chromophore conjugated with the nitrogen substituent of an amino acid or amino alcohol and typically exhibiting UV-absorption maxima in the range of 310 to $360 \mathrm{~nm}$ (Dunlap \& Shick 1998).

Examination of the qualitative and quantitative distribution patterns of MAAs among tropical and warmtemperate to Arctic macroalgae revealed the occurrence of 9 different MAAs, of which 7 could be identified in red algae (Karsten et al. 1998a,b).

Hitherto, only 2 surveys on MAAs in Antarctic organisms have been conducted: by Karentz et al. (1991) and by McClintock \& Karentz (1997). However, these authors focused mainly on marine fauna. Consequently, there are few data available on the occurrence of sunscreening-compounds in macroalgae from the Antarctic region. Therefore, in the present study the patterns and amounts of MAAs were evaluated in a comprehensive set of Antarctic macroalgae, focusing mainly on species collected in the field, supplemented with data on macroalgal cultures. In addition, intraspecific differences in MAA content were correlated with collection depth, as already done for some Arctic red algae (Karsten \& Wiencke 1999, Karsten et al. 1999). In some selected species, MAA concentrations in differ- ent tissues of vegetative and reproductive plants were measured, as well as the physiological capability to form MAAs after transplantation from deeper to shallow waters. Compared to the Arctic Ocean, the Antarctic has some characteristics such as a very small riverine influx that result in low concentrations of DOM and humic substances (gelbstoff) and are reflected in a higher water transparency and thus a higher penetration of UVBR. Therefore, the radiation climate at our study site was characterized and related to MAA content in macroalgal species growing at different depths.

\section{MATERIALS AND METHODS}

Study site and algal material. The investigations were performed at Potter Cove, King George Island, South Shetlands $\left(62^{\circ} 14^{\prime} \mathrm{S}, 58^{\circ} 40^{\prime} \mathrm{W}\right)$, near the Dallmann Laboratory/Jubany Station during austral summer 1997/98 (Fig. 1). Potter Cove is a small fjord divided into an outer and an inner sector. The inner sector has

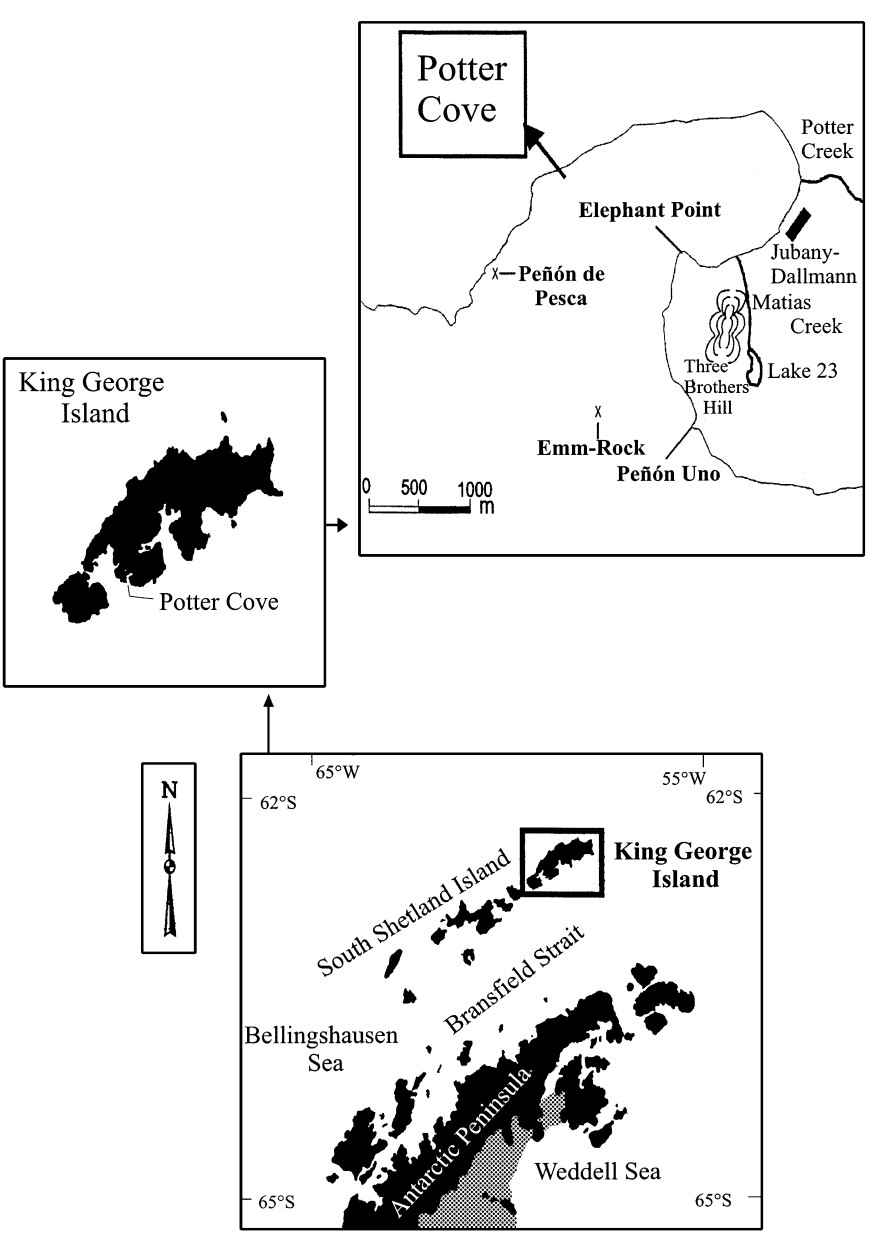

Fig. 1. South Shetland Islands (Antarctica), King George Island, and the study area Potter Cove, with sampling sites indicated 
a muddy bottom and is no deeper than $50 \mathrm{~m}$; the outer area is bordered by steep inclines to the north and by a broad intertidal platform to the southeast. Further descriptions of the environmental parameters of this inlet are given by Klöser et al. (1996 and references therein), and Roese \& Drabble (1998).

Macroalgal species were collected by SCUBA diving at 3 sublittoral stations (Emm Rock [Klöser et al. 1996], Peñón de Pesca [PdP], and Elephant Point) and 1 eulittoral station (Peñón Uno [P1], characterized by rocky flats) (Fig.1). The locations, habitats, and some physiological data on the macroalgal species studied are listed in Table 1, as well as details of the cultured Rhodophyceae investigated. The latter were isolated from Potter Cove in 1994 according to Wiencke (1988) and established as a permanent growth culture in the laboratory under the following conditions: culture medium (Starr \& Zeikus 1987), salinity of 30 to $32 \mathrm{ppt}$, aerated with membrane-filtered air (pore size $0.2 \mu \mathrm{m}$ ), temperature of $0^{\circ} \mathrm{C}$, illumination of 10 to $20 \mu \mathrm{mol}$ photons $\mathrm{m}^{-2} \mathrm{~s}^{-1}$ provided by daylight fluorescent lamps (Lumilux Deluxe, Osram, Germany). Daylength varied between 5 (winter) and $20 \mathrm{~h}$ (summer), simulating fluctuating Antarctic daylengths (Wiencke 1990). The harvested plants were oven-dried at $50^{\circ} \mathrm{C}$ overnight, and then stored in sealed plastic bags under dry and dark conditions prior to MAA analysis.

Radiation measurements. During the summer period, photosynthetically active radiation (PAR, 400 to $700 \mathrm{~nm}$ ) in the atmosphere was measured continuously with a Li-Cor data-logger (LI-1000, Li-Cor, Lincoln, USA) equipped with a flat-head sensor (LI-190). The instantaneous PAR data ( $\mu \mathrm{mol}$ photons $\mathrm{m}^{-2} \mathrm{~s}^{-1}$ ) were plotted against time of day (h), and the total daily photon exposure $\left(\mathrm{mol} \mathrm{m} \mathrm{m}^{-2} \mathrm{~d}^{-1}\right)$ was calculated by integrating the area under the light-time curves. Underwater light measurements were monitored using an underwater spherical quantum sensor (LI 193 SA). Additionally, underwater spectra of ambient radiation of the wavelength from 327 to $700 \mathrm{~nm}$ were recorded at various depths with a spectroradiometer (Ingenieurbüro M. Kruse, Stubben, Germany). Water transmittance was determined by measuring irradiance at different depths and calculating diffuse vertical attenuation coefficients of downward irradiance $\left(K_{\mathrm{d}}\right)$ according to the formula:

$$
K_{\mathrm{d}}=1 /\left(z_{2}-z_{1}\right) \times \ln E_{\mathrm{d}\left(z_{1}\right)} / E_{\mathrm{d}\left(z_{2}\right)}
$$

where $E_{\mathrm{d}\left(z_{1}\right)}$ and $E_{\mathrm{d}\left(z_{2}\right)}=$ irradiances at depths $z_{1}$ and $z_{2}$, respectively (Kirk 1994).

UVBR (280 to $320 \mathrm{~nm}$ ) in the air was measured using a 32-channel single-photon counting spectroradiometer developed at the Physics Department of the Alfred Wegener Institute and installed on the roof of the Dallmann Laboratory. The spectroradiometer was computer controlled, allowing on-line recordings of the radiation data.
MAA concentrations in individuals from different depths and in different tissues and developmental stages. To study intraspecific variations of quantitative and qualitative MAA contents in relation to depth zonation, the red algae Iridaea cordata, Palmaria decipiens, Myriogramme mangini and Plocamium cartilagineum were collected at depths of 0 to $20 \mathrm{~m}$ at Emm Rock and P1 (Fig. 1). Kallymenia antarctica and Gigartina skottsbergii were collected at PdP at depths of 10 and $15 \mathrm{~m}$, respectively.

Quantitative and qualitative variations in MAA contents of different tissues were determined in different parts of selected species as well as in different stages of development, in tetrasporophytic and gametophytic plants.

Two species, Kallymenia antarctica and Gigartina skottsbergii, were collected at $20 \mathrm{~m}$ depth and transplanted into floating UV-transparent XT Plexiglas tubes $(300 \times 110 \mathrm{~mm}$ outer diameter; Weissig, Berlin, Germany) fixed at $0.3,5,10$, and $20 \mathrm{~m}$ water depth. Plexiglas tubes were fastened to a plastic tube of $5 \mathrm{~m}$ length. A buoy was attached to each end of the plastic tube; 1 buoy was fixed with an anchor to the sea bottom. For each species and depth, 3 UV transparent Plexiglas tubes were mounted together, one of which was wrapped with a specific filter foil to cut-off UV-B (320 nm cut-off: Ultraphan URUV, Digefra, München, Germany) and another one to cut off UV-B + UV-A (400 nm cut-off: Folex PR, Folex, Dreieich, Germany). After $8 \mathrm{~d}$ exposure at the respective depths the specimens were harvested for MAA analysis.

MAA extraction and analysis. Samples of about 10 to $20 \mathrm{mg}$ dry weight (DW) were extracted for 1.5 to $2 \mathrm{~h}$ in screw-capped centrifuge vials filled with $1 \mathrm{ml} 25 \%$ aqueous methanol (v/v) and incubated in a waterbath at $45^{\circ} \mathrm{C}$. This procedure was sufficient to obtain $>99.5 \%$ of MAAs in solution. After centrifugation at $5000 \times g$ for $5 \mathrm{~min}, 800 \mu \mathrm{l}$ of the supernatants were evaporated to dryness under vacuum (Speed Vac Concentrator SVC $100 H)$. Dried extracts were re-dissolved in $800 \mu 100 \%$ methanol and vortexed for $30 \mathrm{~s}$. Samples were analysed with a Waters high-performance liquid chromatography (HPLC) system according to the method of Karsten \& Garcia-Pichel (1996), modified as follows. The MAAs were separated on a stainless-steel Knauer Spherisorb RP-8 column $(5 \mu \mathrm{m}, 250 \times 4 \mathrm{~mm}$ i.d. $)$ protected with an RP- 8 guard cartridge $(20 \times 4 \mathrm{~mm}$ i.d. $)$. The mobile phase was 5 to $25 \%$ aqueous methanol $(\mathrm{v} / \mathrm{v})$ plus $0.1 \%$ acetic acid (v/v) in water, run isocrati-

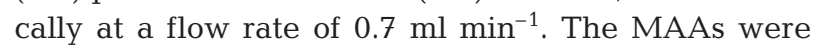
detected with a photodiode detector at $330 \mathrm{~nm}$, and absorption spectra (290 to $400 \mathrm{~nm}$ ) were recorded each second directly on to the HPLC-separated peaks. Identification was by spectra, retention time, and by cochromatography with standards extracted from the 


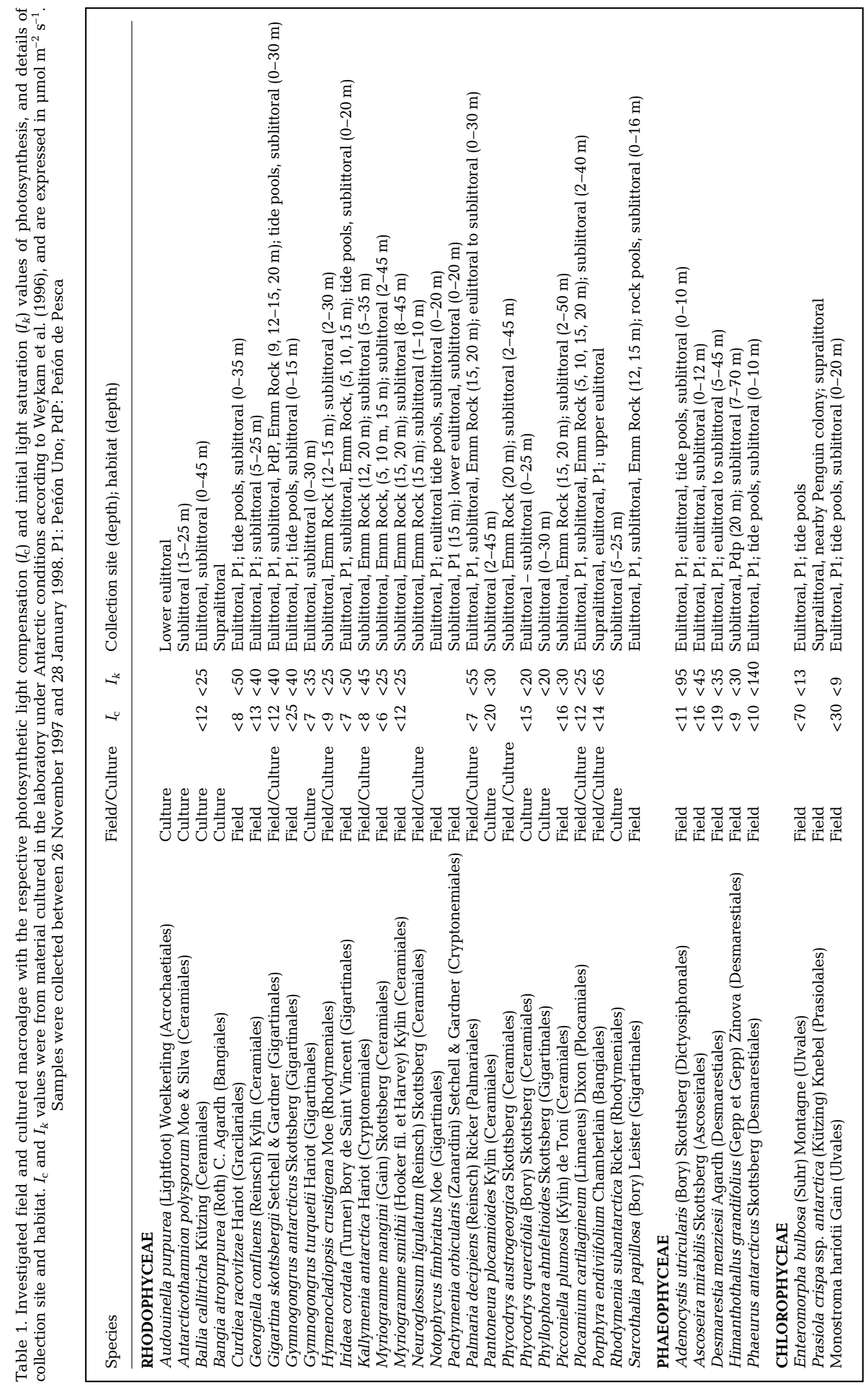


marine red macroalgae Chondrus crispus (Karsten et al. 1998a) and Porphyra umbilicalis (kindly provided by Dr L. A. Franklin, Australian National University, Canberra, Australia). Quantification was performed using the molar extinction coefficients listed in Karsten et al. (1998c). Some smaller amounts of unknown UV-absorbing compounds were summarized and, together with the unknown peaks in Prasiola crispa ssp. antarctica, quantified using an average molar extinction coefficient of all published values. All amounts are given as means of 3 replicates $( \pm$ SD) randomly collected from the respective habitat or from cultures and expressed as concentration on a dry weight basis $\left(\mathrm{mg} \mathrm{g}^{-1} \mathrm{DW}\right)$.

\section{RESULTS}

\section{Radiation data}

Between 1 November 1997 and 31 January 1998, ozone concentration over Antarctica (Neumayer Station) ranged from 227 to 316 Dobson units (DU) (Table 2). During this period, cloud cover was mostly $80 \%$ (6.4 octas) on King George Island, hence influencing surface irradiance. The lowest PAR-dose was $17.4 \mathrm{~mol}$ photons $\mathrm{m}^{-2} \mathrm{~d}^{-1}$ measured on 2 January 1998 at a daylength of $20 \mathrm{~h}$. However, on 1 December 1997 with a cloud cover of only $60 \%$ (4.8 octas) the maximum daily PAR-dose reached $67.2 \mathrm{~mol}$ photons $\mathrm{m}^{-2} \mathrm{~d}^{-1}$. Instantaneous PAR values occasionally even exceeded $1700 \mu \mathrm{mol}$ photon $\mathrm{m}^{-2} \mathrm{~s}^{-1}$ and $1.8 \mathrm{~W} \mathrm{~m}^{-2}$ for UVBR. The maximum daily dose of UVBR in the air was $52.4 \mathrm{~kJ} \mathrm{~m}^{-2}$ on 23 Decem-

Table 2. Radiation measurements and ozone data for the expedition period (22 November 1997 to 31 January 1998). Ozone data taken from Meterology Observatory of Neumayer Station, Antarctica ( $\left.70^{\circ} 37^{\prime} \mathrm{S}, 8^{\circ} 22^{\prime} \mathrm{W}\right)$. DU: Dobson units

\begin{tabular}{|c|c|c|}
\hline & Date & Units \\
\hline \multicolumn{3}{|l|}{ Ozone } \\
\hline Max. ozone & 8 December 1997 & $316 \mathrm{DU}$ \\
\hline Min. ozone & 16 November 1997 & $227 \mathrm{DU}$ \\
\hline Ozone mean value & November 1997-January 1998 & $260 \mathrm{DU}$ \\
\hline \multicolumn{3}{|l|}{ Atmosphere } \\
\hline \multicolumn{3}{|l|}{ PAR (400-700 nm) } \\
\hline Daily dose & Average for December 1997 & 50.1 mol photons $\mathrm{m}^{-2} \mathrm{~d}^{-1}$ \\
\hline Daily dose & Average for January 1998 & 32.9 mol photons $\mathrm{m}^{-2} \mathrm{~d}^{-1}$ \\
\hline Max. irradiance & 20 January 1998 & $1748 \mu \mathrm{mol}$ photons $\mathrm{m}^{-2} \mathrm{~s}^{-1}$ \\
\hline \multicolumn{3}{|l|}{ UVB (280-320 nm) } \\
\hline Daily dose & Average for December 1997 & $40.8 \mathrm{~kJ} \mathrm{~m}^{-2}$ \\
\hline Daily dose & Average for January 1998 & $29.9 \mathrm{~kJ} \mathrm{~m}^{-2}$ \\
\hline Max. radiation & 23 December 1997 & $1.80 \mathrm{~W} \mathrm{~m}^{-2}$ \\
\hline \multicolumn{3}{|c|}{ Attenuation coefficient $\left(K_{d}\right)$} \\
\hline$K_{\mathrm{d} \text { PAR }}$ & 30 December 1998, Emm Rock & $0.17 \mathrm{~m}^{-1} ; 1 \%$ depth: $26.9 \mathrm{~m}$ \\
\hline$K_{\mathrm{d}} \mathrm{UV}(327-399 \mathrm{~nm})$ & 30 December 1998, Emm Rock & $0.19 \mathrm{~m}^{-1} ; 1 \%$ depth: $24.2 \mathrm{~m}$ \\
\hline$K_{\mathrm{d} \text { PAR }}$ & 30 December 1998, Elephant Point & $0.45 \mathrm{~m}^{-1} ; 1 \%$ depth: $10.3 \mathrm{~m}$ \\
\hline$K_{\mathrm{d}} \mathrm{UV}(327-399 \mathrm{~nm})$ & 30 December 1998, Elephant Point & $1.1 \mathrm{~m}^{-1} ; 1 \%$ depth: $4.2 \mathrm{~m}$ \\
\hline
\end{tabular}

ber 1997, with an average daily dose of $40.8 \mathrm{~kJ} \mathrm{~m}^{-2}$, whereas the average daily dose in January 1998 was $29.9 \mathrm{~kJ} \mathrm{~m}^{-2}$. In general in December 1997, PAR and UVR were higher than in January 1998. The light transmittance in the water was much lower in the middle of the bay at Elephant Point than in the outer part at Emm Rock (Fig. 1). The $K_{\mathrm{d}}$ value for PAR at Elephant Point was $0.45 \mathrm{~m}^{-1}$, and UV (327 to $\left.399 \mathrm{~nm}\right)=1.1 \mathrm{~m}^{-1}$, while at Emm Rock $K_{\mathrm{d} \text { PAR }}=0.17 \mathrm{~m}^{-1}$ and $K_{\mathrm{d} \text { UV }}=0.19 \mathrm{~m}^{-1}$, as measured on 30 December 1997. Radiation data for the period of the field study are summarized in Table 2 .

\section{MAA inventory}

Eighteen different species of Rhodophyceae were collected, mostly from the sublittoral or from eulittoral locations (tide pools) at Potter Cove. In the investigated algae, 7 different MAAs were detected. These were identified as mycosporine-glycine, shinorine, porphyra-334, palythine, asterina-330, palythinol and palythene. Furthermore, some smaller amounts of unknown UV-absorbing compounds with retention times between 4.5 and $6.0 \mathrm{~min}$ and absorbance maxima of 332 to $334 \mathrm{~nm}$ were summarized as Unknown ${ }^{1}$ and some with retention times between 6.1 and $15.0 \mathrm{~min}$ and absorbance maxima of 321 to $337 \mathrm{~nm}$ as Unknown ${ }^{2}$ (Table 3). Generally, in $70 \%$ of the field-grown algal species studied, shinorine and palythine were the most abundant MAAs, followed by porphyra-334 and asterina-330, which occurred in half the investigated species. However, in Porphyra endiviifolium, porphyra-334 was quantitatively the most abundant MAA (7.7 $\left.\mathrm{mg} \mathrm{g}^{-1} \mathrm{DW}\right)$. This species also exhibited the highest total MAA content $(9.0 \mathrm{mg}$ $\left.\mathrm{g}^{-1} \mathrm{DW}\right)$, followed by Curdiea racovitzae with a total amount of $4.0 \mathrm{mg} \mathrm{g}^{-1}$ DW. MAAs were completely absent from 4 species $(\mathrm{Hy}$ menocladiopsis crustigena, Myriogramme smithii, Phycodrys austrogeorgica and Picconiella plumosa). These red algae all originated from the sublittoral. Only traces of 3 MAAs were detected in the sublittoral Georgiella confluens.

In 9 of 18 cultivated red algae investigated, no trace of any MAA could be detected. In the remaining plants, the most abundant and the quantitatively dominant MAA was porphyra-334 followed by shinorine (Table 3). Bangia atropurpurea contained the highest 


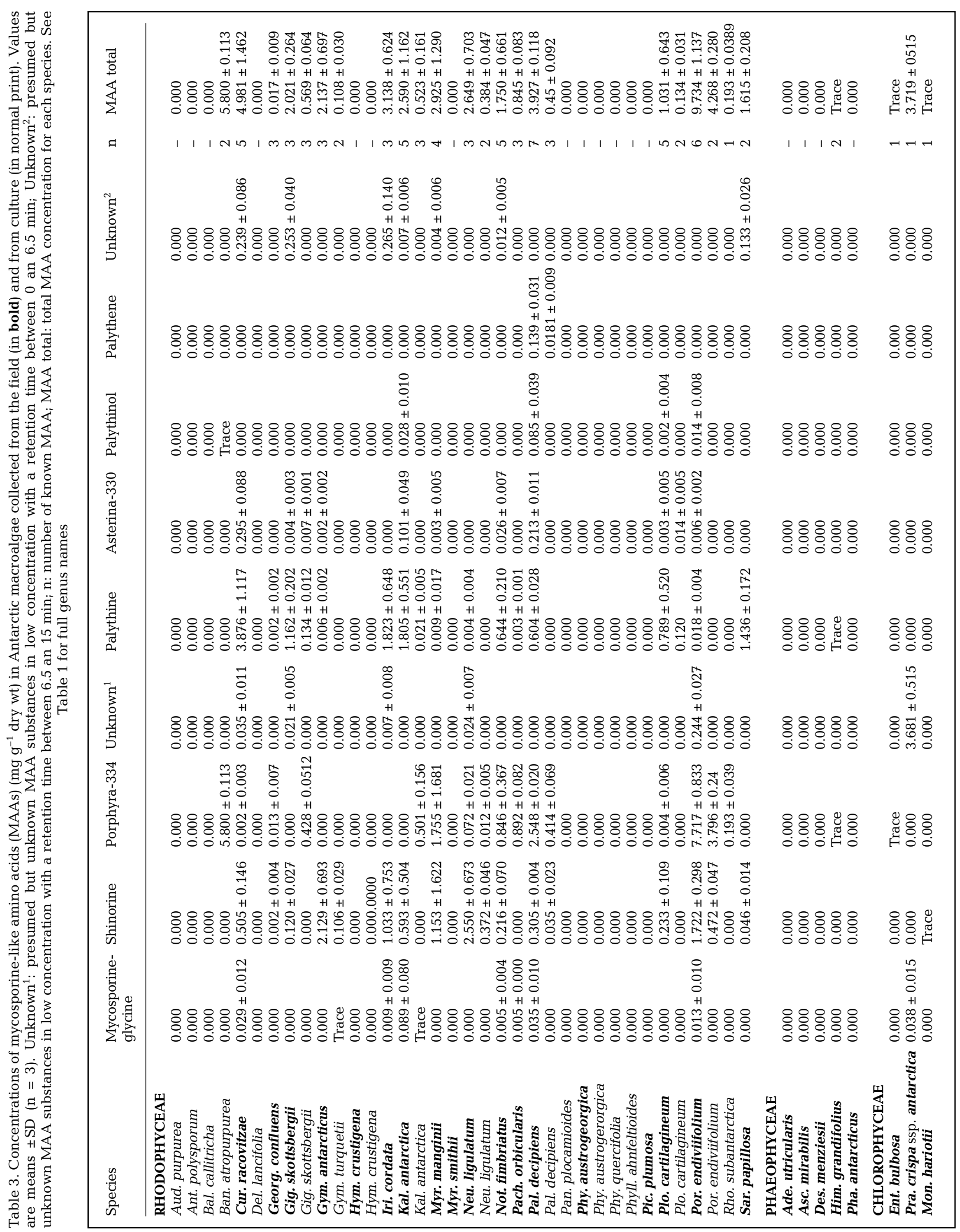


quantity of total MAAs (5.8 $\left.\mathrm{mg} \mathrm{g}^{-1} \mathrm{DW}\right)$, mainly due to the presence of porphyra-334. The MAA content in cultivated plants was generally only 15 to $25 \%$ of values found in algae collected in the field. One exception was Porphyra endiviifolium, which in culture exhibited $50 \%$ of the total MAA value of the field sample. In contrast, cultivated Plocamium cartilagineum contained only $10 \%$ of the total MAAs found in field material. Hymenocladiopsis crustigena did not contain any MAA, either as field-collected alga or as cultured plant (Table 3).

Traces of MAAs were found in 1 Antarctic fieldcollected phaeophyceaen, and all 3 tested chlorophyceaens contained MAAs. Enteromorpha bulbosa contained low concentrations of porphyra-334, and Monostroma hariotii a low amount of shinorine. In Prasiola crispa ssp. antarctica, traces of mycosporineglycine and a high quantity of an unknown UVabsorbing substance ( $3.7 \mathrm{mg} \mathrm{g}^{-1} \mathrm{DW}$ ) with an absorption maximum at $324 \mathrm{~nm}$ and a retention time of 3.2 min were detected, appearing during HPLC analysis before shinorine (retention time $=3.4 \mathrm{~min}$ ) and porphyra-334 (retention time $=4.0 \mathrm{~min}$ ) (Fig. 2).

The initial light saturation $\left(I_{k}\right)$ value of red algal photosynthesis (Table 1) correlated well with the MAA concentration (Table 3), as indicated by a correlation coefficient of $r=0.831$ (Fig. 3). The higher the $I_{k \prime}$ the higher the MAA content.

\section{Depth profile}

In Iridaea cordata, Palmaria decipiens and Plocamium cartilagineum, MAA concentrations continuously decreased with increasing collection depth. Generally, the MAA contents of these species were 1.5 to 20 times higher in shallow-water isolates than in the respective deep-water samples (Fig. 4). While in samples of I. cor- data from shallow-water depths palythine was the quantitatively dominant MAA, in sublittoral plants the concentration of palythine decreased so that shinorine and palythine displayed almost the same concentration (Fig. 5a). When collected from shallow water, Palmaria decipiens exhibited 7 different MAAs; when collected from $20 \mathrm{~m}$ it showed, only 3 , and in very low amounts (Fig. 5b). In contrast to these species, Kallymenia antarctica and Gigartina skottsbergii collected at different depths did not show significant differences in MAA concentrations (data not shown).

\section{Tissue gradient}

The MAA content was measured in different tissues of vegetative algal thalli of Iridaea cordata, Palmaria decipiens and Curdiea racovitzae. The algae exhibited a clear difference in MAA content between the young margin and the older base of the thallus: the margin tissue always contained a 1.5- to 3.6-fold higher MAA concentration (Fig. 6). The content of the quantitatively dominant MAA palythine in the margin tissue of I. cordata was 6 times, and in C. racovitzae 1.4 times, higher than that of basal tissue, whereas porphyra-334, the main compound in $P$. decipiens, increased 4 -fold (data not shown).

\section{Developmental stages}

The tetrasporophytes and gametophytes of Gigartina skottsbergii and Iridaea cordata collected from the sublittoral contained nearly equal MAA concentrations. While the different development stages of the former contained MAA values between 2 and $2.5 \mathrm{mg}$ $\mathrm{g}^{-1} \mathrm{DW}$, the latter species contained between 3.1 and $3.3 \mathrm{mg} \mathrm{g}^{-1}$ DW MAA.
Fig. 2. (a) Prasiola crispa ssp. antarctica and (b) Porphyra ediviifolium. Highperformance liquid chromatography chromatograms of (a) methanolic $P$. crispa ssp. antarctica extract recorded at $330 \mathrm{~nm}$ and the respective absorption spectra between 280 and $400 \mathrm{~nm}$ for each separated peak (peak identities are: 1 , mycosporine-glycine [retention time, $\mathrm{RT},=2.8 \mathrm{~min}]_{i} 2$, unknown MAA [RT $=3.2 \mathrm{~min}]$ ) and (b) Porphyra endiviifolium showing 2 typical peaks $(1$, shinorine $[\mathrm{RT}=3.4 \mathrm{~min}], 2$, porphyra-334 [RT $=4.0 \mathrm{~min}]$ ). Mobile phase: $5 \%$ aqueous methanol $(\mathrm{v} / \mathrm{v})$. AU: absorption units, WL: wavelength

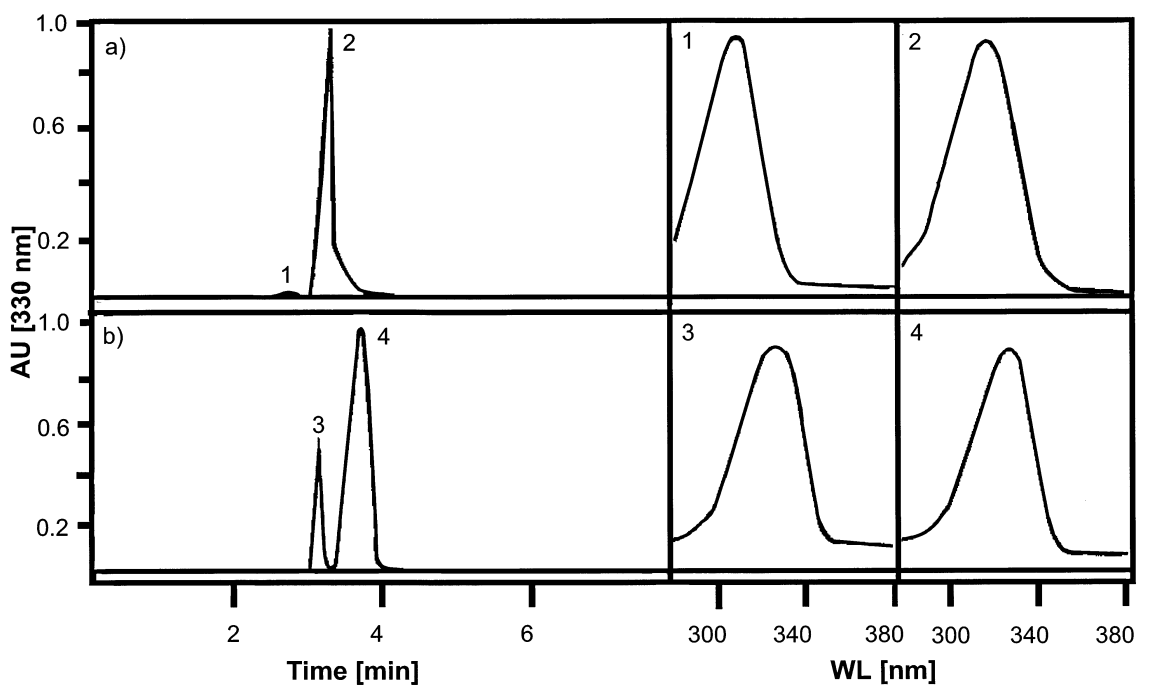




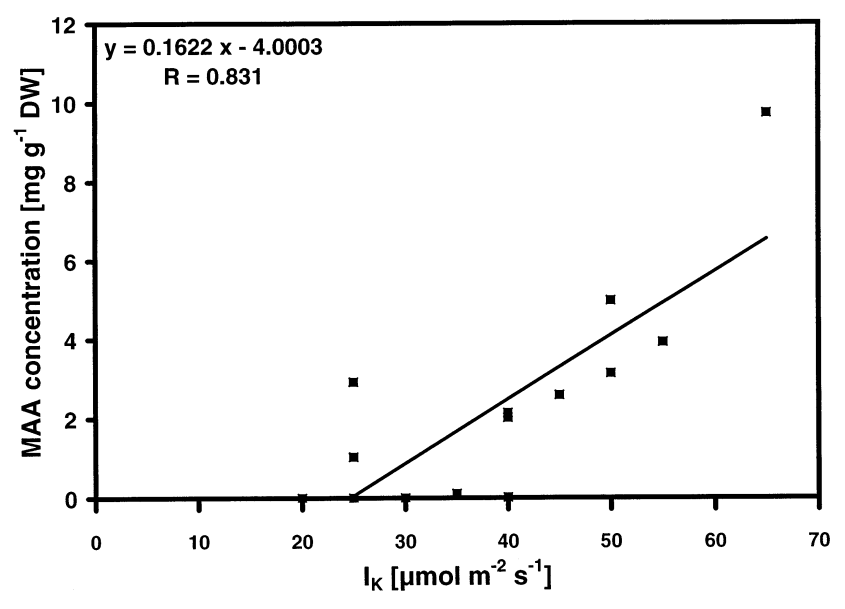

Fig. 3. Initial light-saturation points $\left(I_{k}\right)$ of red algal photosynthesis according to Weykam et al. (1996) plotted against mycosporine-like amino acid (MAA) concentration ( $\mathrm{mg} \mathrm{g}^{-1}$ dry wt, DW) measured in the red algae from the field. Regression analysis: $y=0.162 x-4.0$, with $\mathrm{r}=0.831$

\section{Transplantation experiment}

That total MAA content of Kallymenia antarctica collected from $20 \mathrm{~m}$ was about $2.6 \mathrm{mg} \mathrm{g}^{-1} \mathrm{DW}$ (Fig. $7 \mathrm{a}$ ). After transplantation to $0.3,5,10$, and $20 \mathrm{~m}$ water depth and exposure for $8 \mathrm{~d}$ to solar radiation without UVAR + UVBR, solar radiation without UVBR and full solar radiation, the quantitative and qualitative MAA composition was measured. Although visual evaluation of the data pointed to a slight stimulation of MAA synthesis after transplantation from deeper to shallow water, in most cases statistical treatment (ANOVA, F-test) did not reveal significant differences, with a high standard deviation indicating high variability. Similar results were obtained for Gigartina skottsbergii, in which the total MAA concentration varied from 1 to $2.4 \mathrm{mg} \mathrm{g}^{-1}$ DW under the above-mentioned conditions (Fig. 7b).

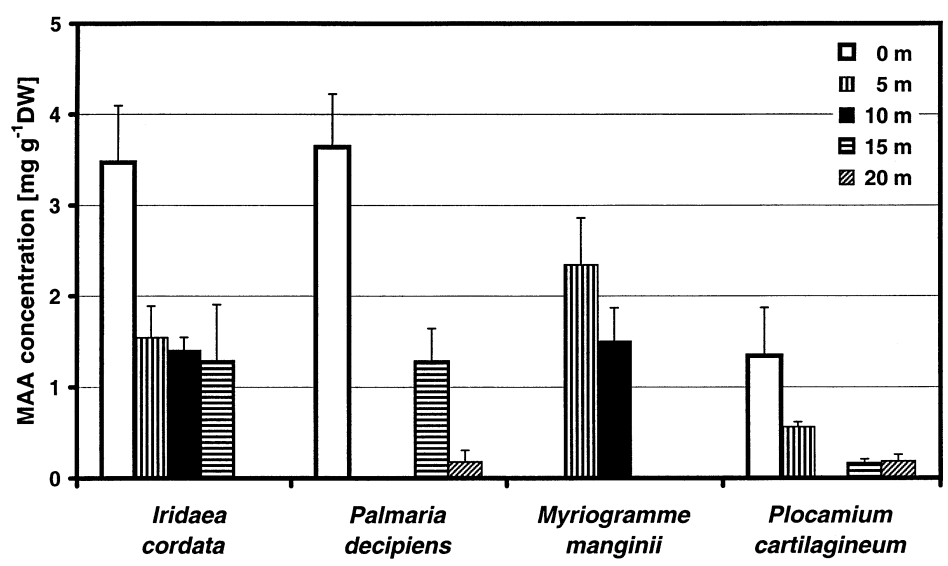

Fig. 4. Effect of increasing collection depth on total MAA content in 4 Antarctic red algae species. Means \pm SD $(n=3)$
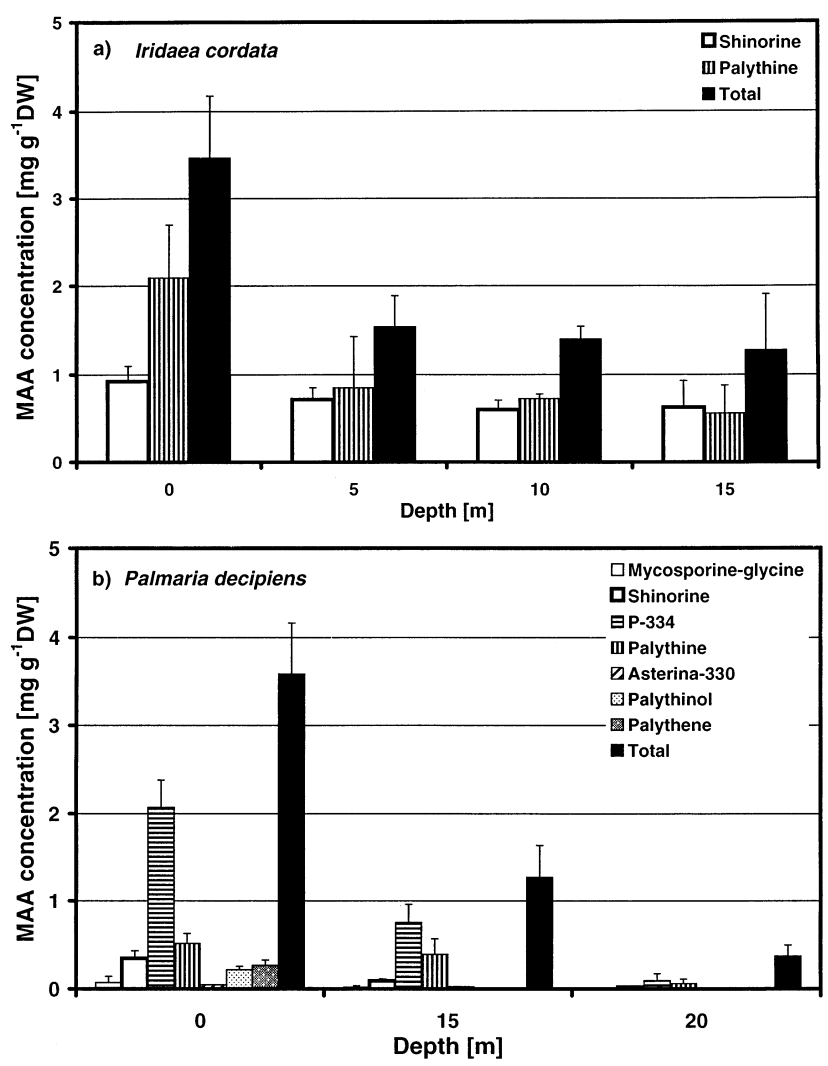

Fig. 5. (a) Iridaea cordata, (b) Palmaria decipiens. Effect of increasing collection depth on concentrations of individual MAAs. Means $\pm \mathrm{SD}(\mathrm{n}=3)$

\section{DISCUSSION}

\section{Radiation data}

The light regime on King George Island changes drastically over the course of the year due to fluctuating daylengths and atmospheric factors such as solar declination and cloud cover. Even during the relatively short study period in the southern summer of 1997/98 radiation data were highly variable. The daily average photon-fluence rate in December 1997 was quite high, at $50.1 \mathrm{~mol}$ $\mathrm{m}^{-2} \mathrm{~d}^{-1}$, compared to other years where maxima of up to $37.9 \mathrm{~mol} \mathrm{~m}^{-2} \mathrm{~d}^{-1}$ were determined (Schloss et al. 1998). Consequently, the daily average of UVBR was also high, at $40.8 \mathrm{~kJ} \mathrm{~m}^{-2}$, even compared with the values in January 1998 $\left(29.9 \mathrm{~kJ} \mathrm{~m}^{-2}\right)$. However, the measurements for January 1998 are in good accordance with data given by Schloss et al. (1998). The maximum PAR value of $1700 \mu \mathrm{mol} \mathrm{m}^{-2} \mathrm{~s}^{-1}$ measured in the present investigation corresponds very well to values reported for King George Island by Hanelt et al. (1994) and Gómez et al. (1997). 


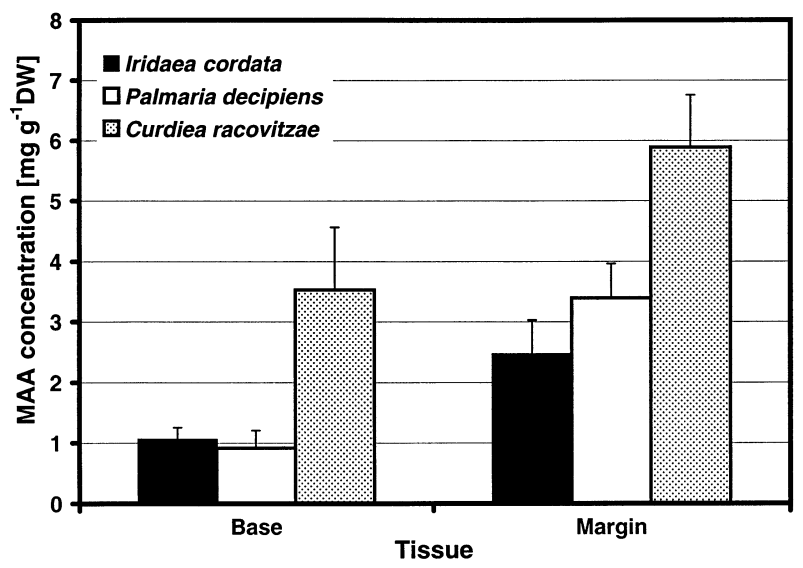

Fig. 6. Total MAA content in different tissues of thallus parts in Antarctic red algae species. Means $\pm \operatorname{SD}(n=3)$
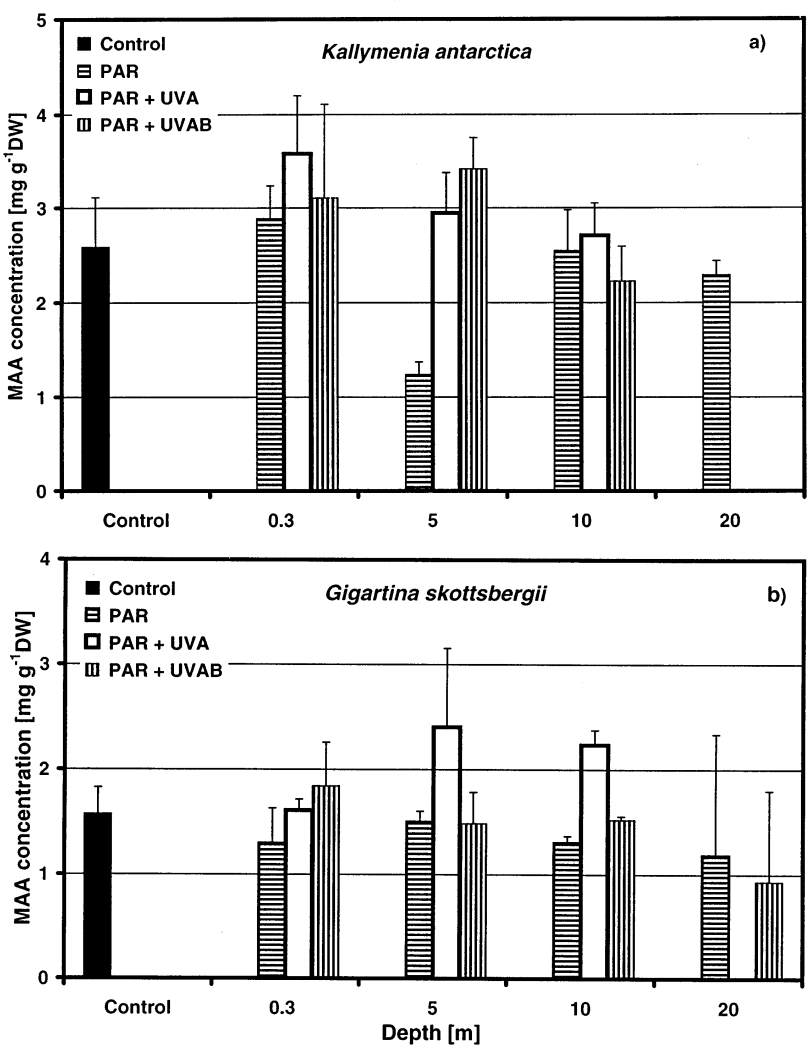

Fig. 7. (a) Kallymenia antarctica, (b) Gigartina skottsbergii. Total MAA concentration after transplantation from $20 \mathrm{~m}$ to shallow water followed by $1 \mathrm{wk}$ exposure under various radiation conditions using specific cut-off filter foils. Means $\pm \mathrm{SD}(\mathrm{n}=4)$

However, the UVB maximum radiation in air of $1.8 \mathrm{~W}$ $\mathrm{m}^{-2}$ is considered to be high for such a high-latitude $\left(62^{\circ} \mathrm{S}\right)$ area compared to data from (e.g.) Southern Spain $\left(38^{\circ} \mathrm{N}\right)$ with values between 1.8 and $2.4 \mathrm{~W} \mathrm{~m}^{-2}$ (Gómez et al. 1998), and to data from Spitsbergen $\left(79^{\circ} \mathrm{N}\right)$, with a value of $1.1 \mathrm{~W} \mathrm{~m}^{-2}$ (Bischof et al. 1998b), and may be explained by the ozone depletion over Antarctica.

Water transparency differed markedly between the stations Elephant Point and Emm Rock. The 1\% depth for PAR-irradiance was restricted to $10 \mathrm{~m}$ at Elephant Point (end of December) because of the increasing discharge of melting water and the suspension of sediment leading to high turbidity of the water column. In contrast, Emm Rock station was only slightly affected by terrestrial influence because of its location in the outer Potter Cove. Here, the measured $1 \%$ depth of $26.9 \mathrm{~m}$ for visible light and $24.2 \mathrm{~m}$ for UV-irradiance (327 to $399 \mathrm{~m}$ ) are comparable with the 1\% PAR depth of $40 \mathrm{~m}$ reported by Gómez et al. (1997), all of these values are characteristic of clear oceanic waters (Smith $\&$ Baker 1981). The data presented are in good agreement with those of Wängberg et al. (1996) and Smith \& Baker (1981), which indicated local very high transparency of Anctarctic waters for UVR, with possible consequential effects for sessile macroalgae, particularly in the upper and mid-sublittoral.

\section{MAA inventory}

UV-absorbing compounds have mainly been reported for macroalgal species of the Rhodophyceae (Karentz et al. 1991, McClintock \& Karentz 1997, Karsten et al. 1998a,b,c). While shinorine and palythine are the predominant MAA compounds of subtidal Antarctic species, in eulittoral plants porphyra-334 is dominant (see Table 3). The highest total MAA concentrations (due to the presence of porphyra-334) were found in the eulittoral and supralittoral species Porphyra endiviifolium (field-collected alga) and Bangia atropurpurea (cultured sample). Both taxa belong to the order Bangiales, which is considered to be primitive due to its simple vegetative and reproductive organisation (Kraft \& Woelkerling 1990), and hence are more ancestral relative to the other 'advanced' Rhodophyceae (Garbary \& Gabrielson 1990). It may be speculated that these genera had to cope with high UVR typical for palaeozoic times and thus developed MAAs as protection mechanism. In our opinion, the capability to synthesize and accumulate such high concentrations of MAAs, as found particularly in $P$. endiviifolium and $B$. atropurpurea, is a conservative trait that allows the species to grow and successfully reproduce today in the intertidal zone of exposed rocky shores where extreme environmental conditions, including UVR stress, prevail.

Most Antarctic macroalgae are adapted to low light conditions, as reflected in the low $I_{\mathrm{c}}$ (light-compensation) and $I_{k}$ values of the photosynthetic irradiance- 
light curves (Wiencke et al. 1993, Weykam et al. 1996). Among the field-collected algae, the species Hymenocladiopsis crustigena, Myriogramme smithii, Phycodrys austrogeorgica, and Picconiella plumosa of the deeper sublittoral are characterized by low $I_{k}$ values $<30 \mu \mathrm{mol}$ $\mathrm{m}^{-2} \mathrm{~s}^{-1}$ and lack MAAs (Tables $1 \& 3$, Fig. 3). They typically inhabit deep waters, grow as understorey species underneath the canopy, and, hence, are well protected from harmful UVBR. Consequently, there is no physiological need to synthesize and accumulate UV-absorbing substances with the concomitant outlay in energy, carbon and nitrogen. In contrast, canopy algae especially in shallow waters, exhibit $I_{k} \mathrm{~s}$ of $>40 \mu \mathrm{mol} \mathrm{m} \mathrm{m}^{-2} \mathrm{~s}^{-1}$, and usually contain high MAA concentrations (Fig. 3).

The few previously published data on MAAs in Antarctic macroalgae (Karentz et al. 1991, McClintock \& Karentz 1997) are in a similar range to those determined here. Small discrepancies can be explained by different collecting times resulting in a seasonal effect, different collecting depths, different hydrographic and atmospheric conditions, as well as by natural species variability.

Compared to the Antarctic Rhodophyceae of the present study, red algae from the Arctic exhibit lower MAA concentrations (Karsten et al. 1998b). Moreover, Antarctic species are characterized by a higher percentage of species capable of synthesizing MAAs. This obvious difference between both floras may be explained by the higher PAR and UVR at King George Island, Antarctica $\left(1748 \mu \mathrm{mol} \mathrm{m}{ }^{-2} \mathrm{~s}^{-1} \mathrm{PAR}, 1.8 \mathrm{~W} \mathrm{~m}^{-2}\right.$ UVBR), compared to Arctic Spitsbergen (1300 $\mu \mathrm{mol}$ $\mathrm{m}^{-2} \mathrm{~s}^{-1} \mathrm{PAR}, 1.1 \mathrm{~W} \mathrm{~m}^{-2}$ UVBR [Bischof et al. 1998b]) as well as by the much clearer water conditions of the Southern Ocean and, thus, higher UV penetration. It is interesting to note that the MAA concentrations detected in Antarctic red algae are similar to those in cold-temperate to warm-temperate species (Karsten et al. 1998b), which are typically exposed to higher solar radiation than polar species. The MAA contents usually correlate with the biogeographic origin and the respective light regime, and hence the proportionally higher MAA values of Antarctic macroalgae may reflect an acclimation to the seasonally enhanced UVR due to ozone depletion. The relatively low MAA concentrations in the cultured algae compared to the field samples can be explained by the low-light conditions in the culture, which did not stimulate biosynthesis and accumulation of MAAs (Karsten et al. 1998a).

In contrast to the Rhodophyceae, extracts of the Phaeophyceae and Chlorophyceae did not show strong absorption in the UV range of the spectrum. The traces of MAAs measured in field samples of the Phaeophyceae might be due to contamination with epiphytic diatoms. These results are in good agreement with those of other studies (Karentz et al. 1991, Karsten et al. 1998 a,b). While Chlorophyceae usually contain only traces of MAAs, the green macroalga Prasiola crispa ssp. antarctica contains high concentrations of an unknown UV-absorbing compound. The occurrence of UVabsorbing substances in P. crispa from Antarctica has been reported earlier (Post \& Larkum 1993, Jackson \& Seppelt 1995). However, all authors extracted their samples in organic solvents, and recorded only absorption spectra on crude extracts obtained by spectrophotometry. Although with this methodology data of ecological importance were obtained, for example seasonally changing absorption patterns, the sunscreen substances involved could not be determined. By using HPLC technology, the present study demonstrates the occurrence of only 1 compound with strong UV-absorbance at $324 \mathrm{~nm}$ in P. crispa ssp. antarctica (Fig. 2).

Prasiola crispa ssp. antarctica is exposed to very extreme environmental conditions in melting or rainwater pools, salt-spray zones of the supralittoral, and even in penguin-rockeries (Jacob et al. 1991), and thereby must cope with large gradients of abiotic factors such as freezing, desiccation, changes in salinity, and high irradiance. This species has developed morphological, physiological and biochemical protective mechanisms such as thick cell walls as a measure against dehydration, temperature-tolerant photosynthetic activity, and the capacity for osmotic acclimation by using sucrose and sorbitol as osmolytes (Jacob et al. 1991, Jackson \& Seppelt 1995). The chemically unknown UV-absorbing substance is considered as photoprotective strategy against UV stress because of its absorbance maximum at $324 \mathrm{~nm}$, i.e. strong absorbance in the UVA/B range.

\section{Depth-dependent MAA accumulation}

The presence of increasing MAA contents with decreasing depth in macroalgae has already been documented for a few species (Franklin et al. 1999, Karsten \& Wiencke 1999, Karsten et al. 1999). These observations are also valid for most of the red macroalgal species investigated in this study. Therefore, the data presented strongly support the hypothesis that MAAs are formed as sunscreen compounds in response to a more stressful situation in shallow waters where they are exposed to increasing UVBR and higher PAR. The 2 exceptions, Gigartina skottsbergii and Kallymenia antarctica, with unchanged MAA concentrations at different depths, can be explained by their already possessing high steady-state MAA values. G. skottsbergii typically occurs in eulittoral pools and in the sublittoral down to $30 \mathrm{~m}$. Although shadeadapted (Wiencke et al. 1993, Weykam et al. 1996), this species can easily acclimate to high irradiances. $K$. antarctica occurs in the sublittoral in a depth range of 
5 to $33 \mathrm{~m}$ only, usually as a canopy plant. This alga has a physiologically high and stable MAA inventory also. In both species, a high basic MAA composition seems to guarantee photoprotection under increasing radiation conditions. Based on photosynthetic studies, Bischof et al. (1998a) reported that UVR is one important factor affecting the vertical distribution of Antarctic macroalgae. The results of these authors are in good agreement with the present study, indicating a negative correlation between MAA contents and depth zonation. However, the transplantation of 2 Antarctic algae ( $G$. skottsbergii and $K$. antarctica) from $20 \mathrm{~m}$ to shallow waters and different, enhanced light conditions did not induce further accumulation of total MAA concentration. This may be simply explained by the relatively high steady-state MAA values in both species and by the relative high water transparency during the experiment. Moreover, the study period ( $8 \mathrm{~d}$ ) may have been too short to induce stronger changes in MAA contents. This contrasts to the situation in Arctic waters, where transplantation experiments showed a clear enhancement of MAA concentration in red algae after transplantion from deeper to shallower water (Karsten \& Wiencke 1999, Karsten et al. 1999).

\section{Tissue gradient}

Karsten \& Wiencke (1999) measured different MAA concentrations along the algal thallus of Palmaria palmata from Spitsbergen. Young apical tips of this alga showed 6- to 8-fold higher MAA amounts than the older basal region. In the 3 Rhodophyceae investigated here, a clear quantitative MAA difference in tissue samples taken from the base and margin of blades was also detected. Marginal tissue exhibiting higher MAA contents is more exposed to solar radiation and usually shows higher growth activities than basal tissue. The cell structure between marginal and basal tissue mostly differs as well, probably resulting in different degrees of cell-wall thickness and vacuolisation. These physiological and structural factors may explain MAA gradients between tissues. The measured high MAA concentrations in marginal or apical thallus regions are in good accordance with the presumed photoprotective function of these compounds.

\section{MAA accumulation in different developmental stages}

Spores are the most sensitive developmental stages against UV stress in the life history of macroalgae, as shown for various brown algae (mostly Laminariales) (Wiencke et al. 2000). The UVR-protective capacity of MAAs on spore-germination and gametophyte devel- opment has recently been demonstrated in the brown alga Laminaria religiosa incubated in the MAA palythine (Makino et al. 1999). Similar studies on red algae are still lacking. Initial data on MAA contents in different developmental stages of Antarctic Rhodophyceae, however, indicate similar MAA concentrations between their isomorphic gametophytes and tetrasporophytes. More pronounced differences can be expected in species with a heteromorphic life history.

The data presented here fully support the proposed sunscreening function of MAAs against the harmful effects of UVR (Dunlap \& Shick 1998). However, the results also show that biosynthesis of MAAs in Antarctic red algae can be not only a plastic physiological process controlled by radiation conditions, as demonstrated in earlier experiments (Franklin et al. 1999, Karsten \& Wiencke 1999, Karsten et al. 1999). The presence or absence of MAAs can also be determined at the genetic level. The capability for MAA biosynthesis may be present in one species and absent from another species of the same genus. Therefore we propose to classify the Rhodophyceae studied into 3 physiological groups. Members of the first group lack any trace of MAA (e.g. Delesseria lancifolia, Phycodrys austrogeorgica). These are mostly deep-water algae with low $I_{k}$ values (Wiencke et al. 1993, Weykam et al. 1996). Moreover, photosynthesis of these species was shown to be particularly sensitive to UVR (Bischof et al. 1998a). Members of the second group (e.g. Palmaria decipiens) always contain MAAs at variable concentrations, depending on environmental conditions. However, in these plants 1 or even several MAAs may be species-specifically involved (Karsten \& Wiencke 1999, Karsten et. al. 1999). Members of the third group (e.g. Kallymenia antarctica) always contain a high suite of MAAs almost irrespective of the environment, particularly of radiation conditions. Species of the last 2 groups are markedly less sensitive to UV exposure than plants of the first group, as indicated by a less strong inhibition of their photosynthesis and a good recovery after exposure to UVR (Bischof et al. 1998a). Phaeophyceae contain only traces of MAAs, and may use other UVabsorbing substances such as polyphenolic compounds to shield UV radiation (Pavia et al. 1997).

In conclusion, the Antarctic macroalgae studied seem to be well adapted to resist UV stress or can acclimate to it through their physiological capability to synthesize MAAs or other sunscreen substances.

Acknowledgements. This project was financially supported by the Deutsche Forschungsgemeinschaft (Ka 899/3-1/-2/-3). The authors would like to thank M. Schwanitz for diving support, C. Gross for processing and providing UVBR data, G. Koenig-Langlo for the ozone data, as well as K. Bischof for technical support and discussion. 


\section{LITERATURE CITED}

Aguilera J, Karsten U, Lippert H, Vögele B, Philipp E, Hanelt D, Wiencke C (1999) Effects of solar radiation on growth, photosynthesis and respiration of marine macroalgae from the Arctic. Mar Ecol Prog Ser 191:109-119

Bischof K, Hanelt D, Wiencke C (1998a) UV-radiation can affect depth-zonation of Antarctic macroalgae. Mar Biol 131:597-605

Bischof $K$, Hanelt D, Tüg $H$, Karsten U, Brouwer PEM, Wiencke C (1998b) Acclimation of brown algal photosynthesis to ultraviolet radiation in Arctic coastal waters (Spitsbergen, Norway). Polar Biol 20:388-395

Cockell CS, Knowland J (1999) Ultraviolet radiation screening compounds. Biol Rev 74:311-345

Collén J, Davison IR (1999) Reactive oxygen production and damage in intertidal Fucus spp. (Phaeophyceae). J Phycol 35:54-61

Dring MJ, Makarov V, Schoschina E, Lorenz M, Lüning K (1996) Influence of ultraviolet-radiation on chlorophyll fluorescence and growth in different life-history stages of three species of Laminaria (Phaeophyta). Mar Biol 126:183-191

Dunlap WC, Shick MJ (1998) Ultraviolet radiation-absorbing mycosporine-like amino acids in coral reef organisms: a biochemical and environmental perspective. J Phycol 34: 418-430

Franklin LA, Yakovleva I, Karsten U, Lüning K (1999) Synthesis of mycosporine-like amino acids in Chondrus crispus (Florideophyceae) and the consequences for sensitivity to ultraviolet B radiation. J Phycol 35:682-693

Garbary DJ, Gabrielson PW (1990) Taxonomy and evolution. In: Cole KM, Sheath RG (eds) Biology of the red algae. Cambridge University Press, Cambridge, p 477-498

Gómez I, Weykam G, Klöser H, Wiencke C (1997) Photosynthetic light requirements, metabolic carbon balance and zonation of sublittoral macroalgae from King George Island (Antarctica). Mar Ecol Prog Ser 148:281-293

Gómez I, Pérez-Rodrígez E, Viñegla B, Figueroa FL, Karsten U (1998) Effects of solar radiation on photosynthesis, UV-absorbing compounds and enzyme activities of the green alga Dasycladus vermicularis from southern Spain. Photochem Photobiol 47:46-57

Hanelt D, Jaramillo JM, Nultsch W, Senger S, Westermeier R (1994) Photoinhibition as a regulative mechanism of photosynthesis in marine algae of Antarctica. Ser Cient INACH 44:67-77

Hanelt D, Wiencke C, Nultsch W (1997) Influence of UV radiation on photosynthesis of Arctic macroalgae in the field. J Photochem Photobiol (Ser B) 38:40-47

Iken K, Quartino ML, Wiencke C (1999) Histological identification of macroalgae from stomach contents of the Antarctic fish Notothenia coriiceps using semi-thin sections. PSZN I: Mar Ecol 20:11-17

Jackson AE, Seppelt RD (1995) The accumulation of proline in Prasiola crispa during winter in Antarctica. Physiol Plant 94:25-30

Jacob A, Kirst GO, Wiencke C, Lehmann H (1991) Physiological responses of the Antarctic green alga Prasiola crispa ssp. antartica to salinity stress. J Plant Physiol 139:57-62

Jeffrey SW, MacTavish HS, Dunlap WC, Vesk M, Groenwoud K (1999) Occurrence of UVA- and UVB-absorbing compounds in 152 species (206 strains) of marine microalgae. Mar Ecol Prog Ser 189:35-51

Karentz D (1989) Report on studies related to the ecological implications of ozone depletion on the Antarctic environment. Antarct J US 24:175-176

Karentz D, McEuen FS, Land MC, Dunlap WC (1991) Survey of mycosporine-like amino acid compounds in Antarctic marine organisms: potential protection from ultraviolet exposure. Mar Biol 108:157-166

Karsten U, Garcia-Pichel F (1996) Carotenoids and mycosporine-like amino acid compounds in members of the genus Microcolens (Cyanobacteria): a chemosystematic study. Syst Appl Microbiol 19:285-294

Karsten U, Wiencke C (1999) Factors controlling the formation of UV-absorbing mycosporine-like amino acids in the marine red alga Palmaria palmata from Spitsbergen (Norway). J Plant Physiol 155:407-415

Karsten U, Franklin LA, Lüning K, Wiencke C (1998a) Natural ultraviolet radiation and photosynthetically active radiation induce formation of mycosporine-like amino acids in the marine macroalga Chondrus crispus (Rhodophyta). Planta 205:257-262

Karsten U, Sawall T, Hanelt D, Bischof K, Figueroa FL, FloresMoya A, Wiencke C (1998b) An inventory of UV-absorbing mycosporine-like amino acids in macroalgae from polar to warm temperate regions. Bot Mar 41:443-453

Karsten U, Sawall T, Wiencke C (1998c) A survey of the distribution of UV-absorbing substances in tropical macroalgae. Phycol Res 46:271-279

Karsten U, Bischof K, Hanelt D, Tüg H, Wiencke C (1999) The effect of ultraviolet radiation on photosynthesis and ultraviolet-absorbing substances in the endemic Arctic macroalga Devaleraea ramentacea (Rhodophyta). Physiol Plant 105:58-66

Kirk JTO (1994) Optics of UV-B radiation in natural waters. E Schweizerbart'sche, Stuttgart

Klöser H, Mercuri G, Laturnus F, Quartino ML, Wiencke C (1994) On the competitive balance of macroalgae at Potter Cove (King George Island, South Shetlands). Polar Biol 14: 11-16

Klöser H, Quartino ML, Wiencke C (1996) Distribution of macroalgae and macroalgal communities in gradients of physical conditions in Potter Cove, King George Island, Antarctica. Hydrobiologia 333:1-17

Kraft GT, Woelkerling WJ (1990) Rhodophyta. In: Clayton $\mathrm{MN}$, King RJ (eds) Biology of marine plants. Longman Melbourne, p 41-85

Larkum AWD, Wood WF (1993) The effect of UV-B radiation on photosynthesis and respiration of phytoplankton, benthic macroalgae and seagrass. Photosynth Res 36:17-23

Lubin D, Frederick JE (1989) The ultraviolet monitoring program at Palmer Station, spring 1988. Antarctic J US 24: 172-174

Madronich S, McKenzie RL, Björn LO, Caldwell MM (1998) Changes in biologically active ultraviolet radiation reaching the earth's surface. J Photochem Photobiol 46:5-19

Makino M, Suzuki M, Yabe K (1999) The influence of ultraviolet irradiation on marine organisms. 3. Effects of ultraviolet absorbing substance, palythine from Chondrus yendoi. Jpn J Phycol (Sôrui) 47:173-177

McClintock JB, Karentz D (1997) Mycosporine-like amino acids in 38 species of subtidal marine organisms from McMurdo Sound, Antarctica. Antarct Sci 9:392-398

Pavia H, Cevin G, Lindgren A, Åberg P (1997) Effects of UV$B$ radiation and stimulated herbivory on phlorotannins in the brown alga Ascophyllum nodosum. Mar Ecol Prog Ser 157:139-146

Post A, Larkum AWD (1993) UV-absorbing pigments, photosynthesis and UV exposure in Antarctica: comparison of terrestrial and marine algae. Aquat Bot 45:231-243

Riegger L, Robinson D (1997) Photoinduction of UV-absorbing compounds in Antarctic diatoms and Phaeocystis antarctica. Mar Ecol Prog Ser 160:13-25 
Roese M, Drabble M (1998) Wind-driven circulation in Potter Cove. Ber Polarforsch 299:40-46

Schloss I, Ferreyra G, Klöser H (1998) Seasonal variation of the conditions for phytoplankton growth in Potter Cove. Ber Polarforsch 299:59-66

Smith RC, Baker KS (1981) Optical properties of the clearest natural waters. Appl Optics 20:177-184

Smith RC, Prézelin BB, Baker KS, Bidigare RR, Boucher NP, Coley T, Karentz D, MacIntyre S, Matlick HA, Menzies D (1992) Ozone depletion: ultraviolet radiation and phytoplankton biology in Antarctic waters. Science 255:952-959

Starr RC, Zeikus JA (1987) UTEX. The culture collection of algae at the University of Texas at Austin. J Phycol (Suppl) 23:1-47

Strid ^, Chow SW, Anderson JM (1994) UV-B damage and protection at the molecular level in plants. Photosynth Res 39:475-489

Wängberg SA, Selmer JS, Eklund NGA, Gustavson K (1996) UV-B effects on nordic marine ecosystem. Tema Nord 1996. Nordic Council of Ministers, Copenhagen

Weykam G, Gómez I, Wiencke C, Iken K, Klöser H (1996)

Editorial responsibility: Otto Kinne (Editor),

Oldendorf/Luhe, Germany
Photosynthetic characteristics and C:N ratios of macroalgae from King George Island (Antarctica). J Exp Mar Biol Ecol 204:1-22

Wiencke C (1988) Notes on the development of some benthic marine macroalgae of King George Island, Antarctica. Ser Cient INACH 37:23-47

Wiencke C (1990) Seasonality of red and green macroalgae from Antarctica - a long-term culture study under fluctuating Antarctic daylengths. Polar Biol 10:601-607

Wiencke C, Rahmel J, Karsten U, Weykam G, Kirst GO (1993) Photosynthesis of marine macroalgae from Antarctica: light and temperature requirements. Bot Acta 106:78-87

Wiencke C, Gómez I, Pakker H, Flores-Moya A, AM, Hanelt D, Bischof K, Figueroa F (2000) Impact of UV radiation on viability, photosynthetic characteristics and DNA of brown algal zoospores: implications for depth zonation. Mar Ecol Prog Ser 197:217-229

Wood WF (1987) Effect of solar ultraviolet radiation on the kelp Ecklonia radiata. Mar Biol 96:143-150

World Meteorological Organization (1998) Press release on 1 October 1998. World Meteorological Organization, Geneva

Submitted: March 8, 2000; Accepted: June 22, 2000

Proofs received from author(s): January 15, 2001 